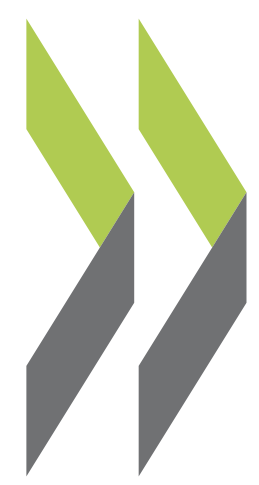

OECD Economics Department Working Papers No. 1014

Why do Russian Firms Use

Fixed-Term and Agency Work Contracts?

Larisa Smirnykh,

Andreas Wörgötter 
Organisation de Coopération et de Développement Économiques

Organisation for Economic Co-operation and Development

14-Jan-2013

ECONOMICS DEPARTMENT

English - Or. English

WHY DO RUSSIAN FIRMS USE FIXED-TERM AND AGENCY WORK CONTRACTS?

ECONOMICS DEPARTMENT WORKING PAPERS No. 1014

by Larisa Smirnykh and Andreas Wörgötter

All OECD Economics Department Working Papers are available through OECD's Internet website at http://www.oecd.org/eco/Workingpapers

JT03333285

Complete document available on OLIS in its original format

This document and any map included herein are without prejudice to the status of or sovereignty over any territory, to the delimitation of international frontiers and boundaries and to the name of any territory, city or area. 


\section{ABSTRACT/RESUMÉ \\ Why do Russian firms use fixed-term and agency work contracts?}

This study looks into the use of fixed term contracts and agency work in Russia during and shortly after the crisis 2009-10 with the help of an enterprise survey. The results of variance analysis show that the use of fixed-term or agency work contracts is not uniform across sectors, size and skill requirements. Probit analysis reveals that the use of fixed term contracts also increases the likelihood of using agency work, but not the other way around. The increase of temporary and agency work contracts increases the turnover on the labour market and contributes to an increase in dualisation, but may also help to prevent a larger increase in unemployment during crisis periods.

JEL Classification codes: $\mathrm{J} 41 ; \mathrm{J} 21 ; \mathrm{J} 63 ; \mathrm{J} 23$

Keywords: labour contracts; employment level; turnover; labour demand; Russia

****************************************************************************

\section{Pourquoi les entreprises russes utilisent les contrats de travail à durée déterminée et de l'Agence?}

Cet article analyse, sur la base de données individuelles issues d'une enquête auprès des entreprises, les principales caractéristiques de l'utilisation de contrats à durée déterminée et du travail intérimaire en Russie pendant la crise 2009-10 et peu après cette période. Les résultats de l'analyse de la variance montrent que l'utilisation de ces contrats n'est pas uniforme et varie selon les secteurs, la taille de l'entreprise et les compétences requises. L'analyse par Probit révèle que l'utilisation de contrats à durée déterminée augmente également la probabilité de recours au travail intérimaire, mais pas l'inverse. L'augmentation des contrats de travail temporaires et intérimaires augmente la rotation de la main d'œuvre sur le marché du travail et contribue à une augmentation du dualisme, mais elle peut aussi contribuer a contenir la hausse du chômage en période de crise.

Classification JEL: J41; J21; J63; J23

Mots-clés: contrats de travail ; niveau de l'emploi ; la demande de travail; Russie

\section{C) OECD (2012)}

You can copy, download or print OECD content for your own use, and you can include excerpts from OECD publications, databases and multimedia products in your own documents, presentations, blogs, websites and teaching materials, provided that suitable acknowledgment of OECD as source and copyright owner is given. All requests for commercial use and translation rights should be submitted to rights@oecd.org. 


\section{TABLE OF CONTENTS}

Why Do Russian Firms Use Fixed-term and Agency Work Contracts? ...................................... 5

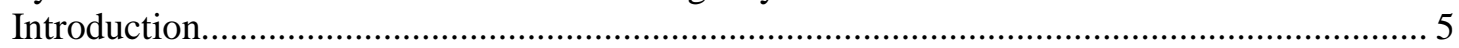

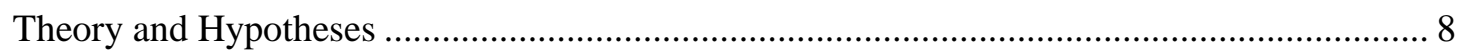

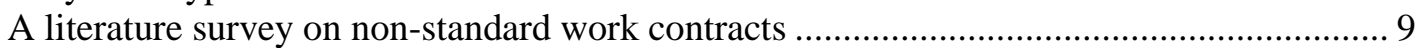

Hypotheses about the demand for non-standard labour contracts.......................................... 9

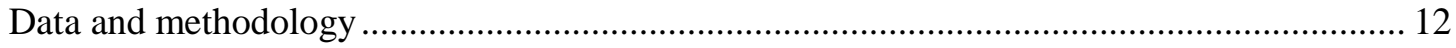

Non-standard labour contracts in Russia .......................................................................... 12

The description of enterprises using non-standard contracts ............................................ 14

The differences of the personnel structure of enterprises depending on the contract form.. 15

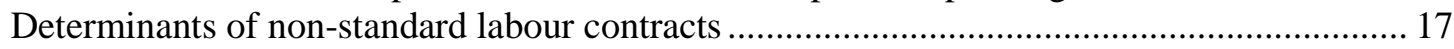

Non-standard labour contracts and Worker Flows ……….................................................... 23

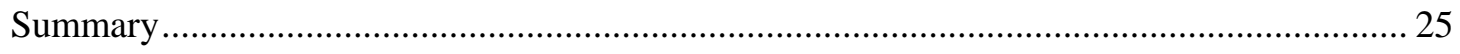

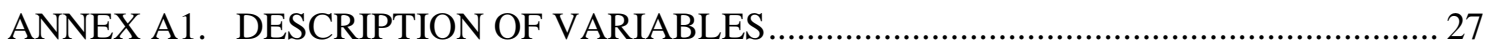

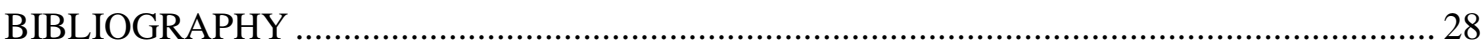

\section{Tables}

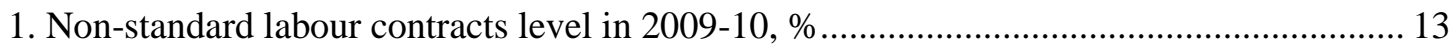

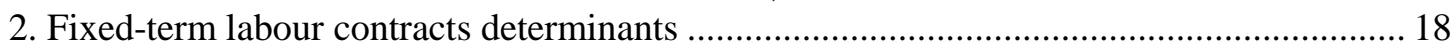

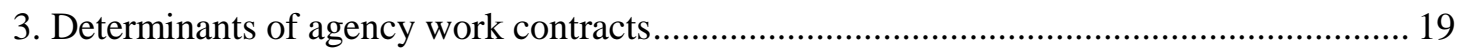

4. Worker Flows and Employment Dynamic at enterprises with different types of labour

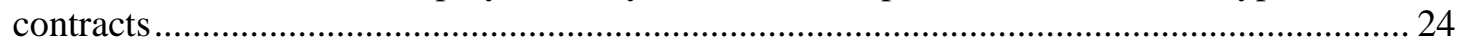

\section{Figures}

1. Share of temporary employment and Employment protection legislation (EPL).................. 6 
ECO/WKP(2013)6 


\title{
WHY DO RUSSIAN FIRMS USE FIXED-TERM AND AGENCY WORK CONTRACTS? ${ }^{1}$
}

\author{
by Larisa Smirnykh ${ }^{2}$ and Andreas Wörgötter ${ }^{3}$
}

\section{Introduction}

There is a growing academic literature on the erosion of the standard work contract and the increasing importance of non-standard ${ }^{4}$ work contracts (Alda/Bellman, 2003; Brinkmann/Doerre/Roebenack, 2006; Keller/Seifert, 2007; Brehmer/Seifert, 2008; Neubäumer/Tretter, 2008; Kalleberg, 2009; Gensicke/Herzog-Stein/Seifert/Tschersich, 2010; Boeri, 2011).

In the academic literature the term ,atypical employment "usually refers to all work contracts, which significantly deviate from the normal work contract (Mückenberger, 1985). Consequently, employment is considered to be atypical if one of the following conditions does not apply: working full time, open-ended contract, fully covered by social security systems, and the identity of the work and employment relationship. (Keller/Seifert, 2007; Destatis, 2008). Typical atypical employment contracts are part-time contracts or labour leasing 5 .

The number of new forms of labour contracts in Russia increases steadily. Nowadays it can be already compared with such European countries as Germany, Greece, Estonia, Lithuania, Poland (Smirnykh, 2010). In other words, non-standard labour contracts are becoming more important for employees and employers on the Russian labour market.

The application of non-standard contracts by enterprises provides more flexibility compared with standard terms of employment, but also increases risks for workers. On the one hand, nonstandard labour contracts allow employers to hire workers at lower costs (there are no costs of job separation) which should support hiring. On the other hand, the application of non-standard contracts by enterprises increases the instability of employment relations and the salary level, which may contribute to income inequality and dualisation as well as the risk of lowering productivity growth because of less investment in human capital by the employer of atypical work.

1. Work on this paper was supported by the "The Basic Research Program" at the National Research University Higher School of Economics (HSE) and prepared for the IZA/HSE Workshop "Labor Market Adjustment in the Commonwealth of Independent States, Central Asia and China in the Wake of the Great Recession" on 5-6 October 2012 in Moscow. The responsibility for this paper is strictly with the authors and opinions and assessments are not necessarily shared by affiliated institutions.

2. Professor of Economics, Laboratory for Labour Market Studies, National Research University - Higher School of Economics, Moscow. E-mail: 1smirnykh@hse.ru.

3. Head of Division, OECD, Economics Department, Paris and Associate Professor, Department of Mathematical Economics, University of Technology, Vienna. E-mail: andreas.woergoetter@oecd.org.

4. In this paper we use the terms non-standard work contracts and atypical employment for temporary and agency work contracts.

5. We use this term also for agency work. In such cases the worker is employed by an agency and works for a company, which has a contract with this agency. 
Most studies investigate the consequences of non-standard labour contracts for workers in particular and the society in general (Boockmann/Hagen, 2006; Kvasnicka, 2008; Autor/Houseman, 2010; Karabchuk, 2012; Jahn, 2010; Jahn/Riphahn/Schnabel, 2012).

Only a few studies look into the motivation behind the employers' demand for temporary contracts and labour leasing (Houseman 2001; Hagen/Boockmann, 2002; Booth/Dolado/Frank, 2002; Pfeifer, 2005; Portugal/Varejao, 2009; Jahn/Bentzen, 2010). Usually enterprises prefer to employ staff on the basis of fixed-term labour contracts than to use open-end contracts for meeting short-term workloads. Thus, the process of recruiting workers can proceed differently at enterprises using non-standard labour contracts compared with those which do not use such contracts, because of a wider range of choices. It can be observed that the share of temporary work contracts is higher in countries, with a more strict employment protection legislation (Figure 1). On one side is the US with its light employment protection and a low share of temporary work contracts and on the other side we find Spain with a high share of temporary workers and very strict employment protection.

Figure 1: Share of temporary employment and Employment protection legislation (EPL)

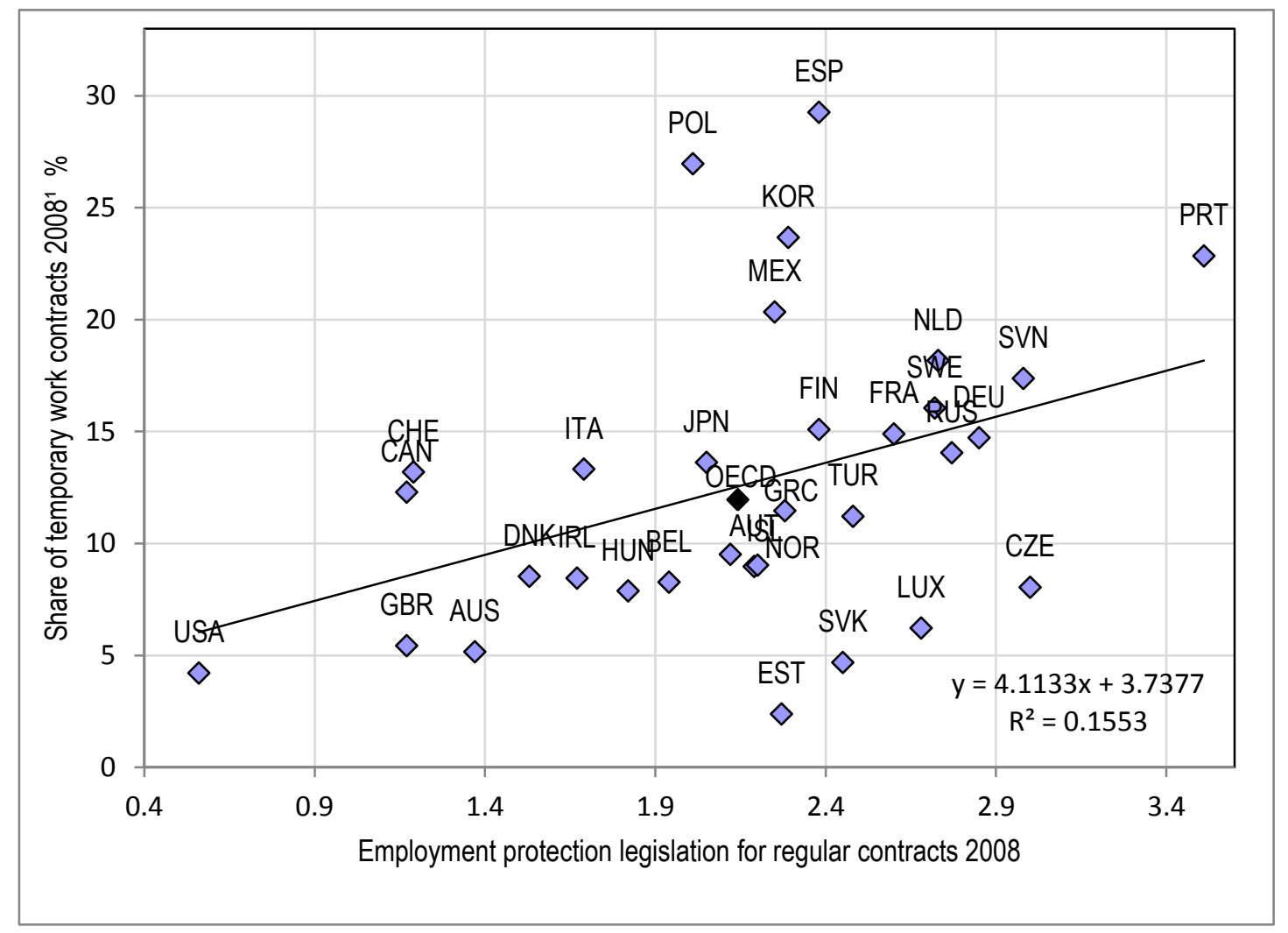

Source: OECD.

In the literature, several reasons have been identified that may render atypical employment profitable. If costs alone would be the only determinant of the choice of the type of labour contract used, then there would be only one or the other, but not standard and non-standard work contracts co-existing. If there are cost-advantages of non-standard work contracts (like the absence of job-termination costs), then companies would employ workers only on the basis of nonstandard work contracts (Pfarr et al., 2004). There must also be other considerations, because we 
observe both standard and non-standard work contracts, although with varying proportions. Therefore it could be that uncertainty could also play a role (Abraham, 1988; Milner/Pinker, 2001). If companies employ a highly specialised labour force and mainly work for volatile foreign and highly profitable demand then it could be that the availability of workers is more important than their costs. It is the interaction of employment protection legislation, the amount of internal (hours and wages) flexibility and the importance of firm specific human capital, which shapes the attractiveness of non-standard work contracts for employers.

In Germany for instance, employment protection legislation is strict, internal flexibility is high and firm specific human capital is important (Hüfner, Klein, Wörgötter, 2012). External flexibility measures therefore mainly take place in form of non-standard work contracts. In Turkey on the other hand, with similarly strict employment protection legislation, external flexibility mainly takes place by movement in and out of informality (Gönenç, 2012). This paper wants to shed some light on where Russia stands in this respect, also because traditional forms of crisis management, like the accumulation of wage arrears is became less acceptable in the recent crisis compared with the banking crisis of the late nineties (OECD, 2009).

Firms can use atypical employment to adjust more efficiently to temporary demand fluctuations (1). If employers are uncertain about whether a rise in demand is temporary or permanent, they will be reluctant to increase the number of regular workers, relying instead on atypical workers until the economic outlook becomes more certain. By employing atypical work, firms may insulate their regular workforce from changing demand conditions (2). This insulation may help firms to reduce firing costs and profit from the availability of firm-specific human capital. It may also be used to obtain wage and work rule concessions from regular workers in exchange for greater employment security (Hüfner, 2012 for Germany). Atypical work may be used in case of temporary absences of regular employees due to illness, holidays or child care leave (3). Firms may use flexible working contracts to screen prospective regular employees (4). The use of atypical workers can be cost-effective for small and medium sized firms (5). They can hire the atypical workers for specific tasks without hiring permanent workers (6).The existence of specialised TWA workers may make it cost-effective for small- or medium-sized firms to hire atypical workers for particular tasks instead of hiring regular workers. Employers may be forced to use secondary workers if they are not able to fill vacancies at prevailing wages (7). Using atypical workers instead of permanent employees may be advantageous for firms in order to avoid paying social security contributions (8). The following empirical analysis will focus on the some of these factors.

The uncertainty about the company's final market demand generates also an uncertainty about the demand for labour, which can be met with more flexibility on the company level and a dualisation of the internal labour market in the company: demand shocks are absorbed by marginal workers in order to avoid laying off the core labour force. For this approach to make sense it is necessary to be able to differentiate the labour contract according to the nature of the human capital of the worker. Workers with very firm-specific human capital are very costly to replace, while for workers with transferable human capital it may not be advantageous to stick with one employer.

A second source of uncertainty is the limited information available ex-ante about the productivity of the worker. The employer can find out more during the probation period, but the usual restriction on the length of the probation period may not be appropriate in all cases. An example is the recruitment of university professors, which is preceded by a limited series of renewable fixed term contracts. Therefore an employer might prefer fixed term contracts in order to gain a full picture about the productivity potential of a worker. In case the true productivity of the 
worker reflects the expectations of the employer and if there is no undue wage differentiation the worker might not refuse a non-standard labour contract if it is an entry ticket for a standard labour contract with sufficient probability. This way the matching fit can be increased and layoffs because of recruiting mistakes can be avoided.

Finally there is some fluctuation of the internal labour supply because of sickness, maternity leaves and other unforeseen absences. In these cases the replacement by temporary work contracts or agency workers is preferable, because it avoids excess fluctuations of the labour force. For the hired worker with a non-standard labour contract there is also an advantage, as long as there is transparency about the non-availability of a standard labour contract.

Under ideal framework regulations (allowing for enough flexibility to respond to external shocks as well as preserving incentives to accumulate productivity increasing firm-specific human capital) workers with a non-standard labour contracts are young (before entering their first standard labour contract, do not cheat about their true productivity or have a high share of general education.

This study investigates factors which increase the probability for a company to use nonstandard work contracts and to employ workers on such contracts. Statistical and econometric methods used to identify such factors are variance analysis and probit and tobit regressions.

Main Questions to be answered are:

- Whether enterprises' benefits from the utilization of non-standard labour contracts are different for small and large-scale enterprises and differ for branches and sectors of the economy

- Whether the employment level at enterprises, using non-standard labour contracts comparing it with enterprises which do not use such labour contracts increases or decreases. The answer for this question is interesting in particular for the crisis period of 2008-09, when the threat of employment termination and unemployment increased.

The paper is organised in five sections. The first section provides a short survey of the literature and derives the main hypotheses which we expect to test empirically. The second section describes the data and methodology. The third describes the evolution of non-standard work contracts in Russia. The fourth section presents the results of the empirical analysis. The fifth section provides an analysis of the impact of non-standard labour contracts on the rates of recruiting, dismissal and employment. The main findings are summarised in the conclusions section.

\section{Theory and Hypotheses}

Employment adjustments can occur in different ways. Firms have several options to react to demand-induced output fluctuation (Pfeifer, 2005). They can use either internal or (and) external forms of flexibility. Firms will normally make use of more than one instrument of adjustment. Each form can be subdivided into functional and numerical flexibility. Instruments of internal labour supply flexibility comprise working time flexibility (overtime, short-time work, flexible work schedules). Instruments of external labour supply flexibility contain employment adjustments (layoffs, hiring, fixed-term contracts). Functional instruments of internal flexibility (inhouse transfers of employees, training and life-long learning) can help to adjust output to shocks or implement strategic restructuring measures without adjusting labour supply. 


\section{A literature survey on non-standard work contracts}

The need for firms to react flexibly on demand fluctuations is discussed since long time (Brodsky, 1994). Companies facing large job-separation and hiring costs and a labour force with a significant share of company specific human capital prefer internal flexibility over external flexibility (Bellmann and Alda, 2004). Instruments used in this respect are functional flexibility, hours flexibility and wage flexibility. However, such forms of flexibility are limited. Wages and hours can vary only within the restrictions set by law and collective agreements, as well as technology specific aspects, which determine the fixed costs of a workplace. Therefore it is not surprising that employers use also external flexibility in the form of fixed term contracts to adjust to demand shocks (Hagen, 2003).

Once the possibilities of internal and functional flexibility are exhausted external flexibility measures (layoffs or hiring new employees) must be applied (Capelli and Neumark, 2001). Usually all forms of hours flexibility are exploited before agency work is used (Bellmann, 2012). Laying off workers is associated with potentially hard to predict separation costs, especially if the job separation involves court proceedings. Temporary contracts and agency work come together with smaller adjustment costs than open-ended (standard) work contracts. According to probit estimates demand fluctuations and employment protection legislation for standard work contracts are a significant factor influencing the demand for non-standard work contracts (Hagen and Bockmann, 2002).

\section{Hypotheses about the demand for non-standard labour contracts}

The following hypotheses (motivated by the theoretical literature) are the basis for the specification of the probit estimates in the subsequent section:

The Russian Labour Code differentiates a lot between regular and temporary work contracts (OECD , 2011). While the regular contract is more protected than in any OECD country except Portugal temporary contracts are much less protected than on average in OECD countries. This is mainly because of a notice period and severance pay obligation of two months, independent of the tenure of the contract in case of job separation of a regular contract. Both regulations are absent for temporary work contracts. This makes a regular contract (possibly much) more expensive than a temporary work contract in the case of filling a vacancy for a predictable time period.

1. Companies use non-standard work contracts for external flexibility in case of demand shocks. They prefer temporary contracts and agency work contracts to avoid the relatively high job-separation costs, which are coming together with hiring workers on open-ended contracts for temporary labour demand needs.

2. Companies prefer internal flexibility over external flexibility. They use external flexibility measures only once internal measures are exhausted. Therefore they use less external flexibility if there is more scope for internal flexibility.

Relative cost advantages play a role for determining the structure of the employed labour force. However, the relative wage costs of labour hired with standard or non-standard contracts is not clear. On one side, the theory of compensating wage differentials (Reference) predicts that non-standard contracts are more expensive, because they have to compensate the lower security and job-protection on such jobs. On the other side, workers employed with non-standard contracts are usually less well organized and have less bargaining power, resulting in lower wages and fewer fringe benefits. Empirical studies find more evidence for a negative wage differential for workers employed with a non-standard contract (Booth, Francesconi and Frank (2002); 
Houseman, 2001; Hagen, 2002; Kwasnicka und Werwatz, 2002, 2003). A wage cost advantage of non-standard work contracts has however to be balanced against the advantages of higher efficiency wages paid for standard wage contracts, which reduce control costs and increase compliance and efforts of the worker. Wage differentials could also be overcompensated by productivity differentials due to missing firm-specific human capital or the lack of commitment. Substitution of standard work contracts through non-standard work contracts is more likely for low productivity workplaces, for which effort and human capital play a less important role and control costs are usually low.

3. Companies demand non-standard work contracts if this reduces overall labour costs.

4. The demand for non-standard work contracts falls with rising firms specific human capital requirements.

5. The lower is the human capital of workers on standard contracts, the higher is the probability that they are replaced by workers with (cheaper) non-standard contracts.

Another explanation for the demand for non-standard work contracts is provided by the existence of an internal, dual labour market in the company (Atkinson, 1987; Kalleberg, 2001; Cappelli/Neumark, 2004). A dual labour market develops because of uncertainty about the demand for the output of the firm. For a profit-maximising company it is preferable to shelter its core workforce with standard contracts from hiring and firing fluctuations and absorb the fluctuations of its labour demand due to fluctuating demand for its output with a marginal labour force employed on non-standard work contracts. Non-standard labour contracts then act as a buffer (Booth/Francesconi/Frank, 2002).

The efficiency wage hypothesis has a different explanation for non-standard contracts: For workplaces and functions with difficult and costly monitoring a core work force with high wages and stable employment relationships develops, while for activities which can be easily monitored workers are employed with (cheaper) non-standard work contracts. (Saint-Paul, 1991, 1996).

Trade unions mainly have members belonging to the core workforce, which further supports the existence of an internal dual labour market as long as this does not erode the sustainability of the core work force because of substitution through the marginal work force working on nonstandard contracts. This also explains why the local trade union in the company usually accept such initiatives from the management, although the central trade union opposes them in principle (Atkinson, 1987). In Germany the probability of non-standard contracts increases with the existence of a collective agreement (Keiser and Pfeiffer, 2000). The ambivalent influence of labour councils is also confirmed in empirical studies for Germany (Boockmann and Hagen, 2003; Dull and Ellguth, 1999).

6. Trade unions support the emergence of a stable core work force and are therefore not against an internal dual labour market with a marginal labour force employed on non-standard contracts as long as this does not threaten the existence of the core workforce.

Technological change and accompanying innovations have an influence on the structure of the workforce. On one side such innovations can simplify work and downgrade skill requirements (cashiers at the supermarket do not need to be able to count any more as a consequence of de-skilling technological change coming together with the bar-code technology). On the other side innovations can also require higher qualifications (skill-biased technological change), for instance computer and internet literacy. If technical progress is weakening the position of unskilled workers in the firm then there might be pressure to accept switching to non-standard con- 
tracts. Skill-biased innovations make monitoring more difficult and thereby favour the core work force and increase the scope for employing a marginal workforce on non-standard contracts.

7. Innovative firms employ are more likely to develop a dual labour market and use non-standard contracts in order to employ more workers on non-standard contracts.

Also the geographical location of a company plays a role (Abraham and Taylor, 1996). Companies in urban areas are more likely to use non-standard labour contracts mainly because the supply of such workers is higher and costs are lower.

8. Companies in urban areas are more likely to employ workers on non-standard labour contracts.

Some authors show that being assigned to a non-standard contract has a causal effect on the probability of finding a permanent match (Ichino et al., 2008, and Booth et al., 2002). According to this view non-standard work contracts are good screening devices and stepping stones into permanent jobs and therefore increase productivity.

Uncertainty about the productivity of a worker is also a motivation for non-standard work contracts. The choice of the right workforce is complicated by the principal-agent information asymmetries (Ichino and Muehlheusser, 2004). Finding the right applicant for a post can also make use of probation periods. However these can be limited by labour regulations, as for instance in Russia, where the length of the probation period is limited to 6 months (Labor Code of RF, 2012). In such cases non-standard labour contracts could act as a circumvention of restrictions of the length of the probation period. This issue could be more important for workforces and employers with high human capital requirements (Loh, 1994).

The strength of this argument depends however on the differentiation of separation costs between temporary and open ended (standard) contracts. Recent labour market reforms go in both directions. In continental Europe many countries relaxed the rules about the use of non-standard contracts with the aim of reducing adjustment costs for firms facing strict EPL for standard openended contracts (Cappellari et al., 2011). On the other hand, recent labour market reforms in Austria, for instance, have transformed the severance pay scheme (which contributes importantly to EPL in most labour regulation systems) into a compulsory savings scheme, thereby reducing disincentives of job separations both for the employer and the employee (OECD, 2004; Box 2.2).

Strict EPL raises the cost of employing workers and reduces labour demand (Lazear, 1990; Cappellari et al., 2011). Increase in EPL may induce a negative effect on productivity: reduces workers effort (Ichino and Riphahn, 2005; Riphahn and Engellandt, 2005; Dolado et al., 2012); reduces the undertaking of highly productive but risky activities (Bartelsman and Hinloopen, 2005). According to this view temporary contracts are good screening devices and stepping stones into permanent jobs and therefore increase productivity.

9. Companies use non-standard work contracts as an extension of probation periods.

Another reason for demanding non-standard work contracts is the need to replace unforeseen absence of members of the core workforce due to for example sickness or maternity leave (Abraham, 1988). In such cases it does not seem to be reasonable to hire a worker on a standard, open-ended contract, because the return of the absent worker would make a costly job termination process for one or the other necessary. Hagen und Boockmann (2002) find that temporary work is used to replace absence because of (longer and predictable) maternity leave, while 
agency work is usually replacing absence due to sick leave, which is less long but also less predictable.

Several studies (Stephan, 1991; Schnabel and Stephan, 1993; Stephan, 1994; Barmby et al., 1995; Barmby and Stephan, 2000) confirm that besides the size of the labour force also the share of women contributes to an increase of absence. On the contrary, absence rates decline with the share of white collar workers and the level of education.

10. The higher is the share of women in a company, the higher is the likelihood of absence from work. Consequently, companies are more likely to use temporary work to deal with such issues.

\section{Data and methodology}

Data used for the present study were obtained in the course of a Survey of Russian Enterprises (RES) ${ }^{6}$ in 2010. The sample included 1010 enterprises of six branches of the economy with more than 50 employees'. Those branches of the economy include mining, manufacturing, construction, transport and communication, trade and finances. The data base obtained includes both the current (2010) and retrospective (2009) information covering enterprises' main characteristics, which are subdivided into four groups. The first group includes factors characterizing the employment structure, including gender and age and its demographic composition. The second includes factors showing enterprises' strategic behaviour (innovations and investments, organizational characteristics), their personnel policy (recruiting and dismissal share, vacancies, employees training, and employees leave without payment, part time employment, and reduction of wages). The third group includes factors of enterprise characteristics (enterprise age, ownership status, its size, industrial sector and the region of its location). And finally, the fourth group includes factors of enterprise's external appraisal of present economic and institutional situation (changes in the course of time, labour legislation appraisal, assessments of factors creating obstacles and threats for enterprise activity).

This paper analyses two types of non-standard labour contracts, which are general fixedterm contracts including all types of fixed-term contracts signed by an enterprise with an employee for a specified period of time and agency work contracts, i.e. when a labour contract for a specified period of time is signed by an employee and employment agency (a company supplying manpower to enterprises for a specified period of time).

The applied research procedure includes a descriptive analysis and estimates based on Probit models of binary choice. Moreover, a heterogeneity test (variance analysis) was carried out to gauge enterprises' diversity by different factors (staff composition, employment conditions and remuneration of labour). Variance analysis is used to test the hypothesis whether the mean values for various labour market characteristics differ between employers with different types of labour contracts.

\section{Non-standard labour contracts in Russia}

According to RES about two fifth of Russian enterprises used non-standard labour contracts in 2009 and 2010 (Table 1). The share of enterprises with non-standard labour contracts was in-

6. Survey of enterprises conducted by a study of the labor market laboratory at the NRU Higher School of Economics, Moscow, from 2009. Funding for the survey of enterprises was provided by a project of the "Basic Research Program" (NRU Higher School of Economics, Moscow). 
creasing by 3.2 percentage points between 2009 (39.9\%) and 2010 (43.1\%). Enterprises found fixed-term labour contracts more attractive than agency work. Thus the share of enterprises with fixed-term labour contracts in the total number of enterprises was in 2009-2010 much higher (37.4\% and 39.8\%) than the share of enterprises using agency work contracts (2.5\% and 3.3\%). In comparison, in Germany about as many (3\%) enterprises use agency work, but much fewer enterprises (17\%) use temporary work contracts (Hohendanner/Gerner, 2010; IAB, 2009).

The dynamics on non-standard work contracts in Russia is characterised by much faster growth of agency work (albeit from a much lower level) than fixed term contracts. In 2009 the number of enterprises using fixed-term labour contracts exceeded the number of enterprises with agency work contracts by 15 times though in 2010 this ratio decreased to 12 times. This reduction took place because of the significant increase of the number of enterprises using agency work contracts. The utilization of these contracts increased by $32 \%$ in 2010 compared with 2009 while the number of companies with fixed-term labour contracts increased by only $6 \%$, although the number of contracts per company increased as well.

Summing up, the utilization of non-standard labour contracts increased at Russian enterprises in 2009-10, mostly due to the increase in the use of agency work contracts, albeit from a small level, which is however of similar size as in Germany.

Together with the increasing number of enterprises using non-standard labour contracts, the number of employees recruited under the conditions of these contracts was growing as well. In 2009-10, the percentage of employees working on the basis of fixed-term labour contracts in the total number of employees was equal to 5-6\% and this value for those working under the terms agency work contracts was equal to less than $1 \%$ (Table 1). In Germany the absolute numbers are similar, but the increase of non-standard work contracts is more evident for fixed term contracts. In 2010, more than 9 percent of all employees fully covered by social security in Germany are employed under a fixed-term contract (Nielen and Schiersch, 2012). In 2000 this was only about 6 percent (Gundert and Hohendanner, 2011). About $2 \%$ of all employees in 2008 were agency workers (IAB, 2008).

Table 1. Non-standard labour contracts level in 2009-10, \%

\begin{tabular}{lrr}
\hline \multicolumn{1}{c}{ Types of contracts } & \multicolumn{2}{c}{ Years } \\
\cline { 2 - 3 } & 2009 & $2010^{\prime}$ \\
\hline Firms with fixed-term contracts & 37.4 & 39.8 \\
Share of employees with fixed-term contracts (basis: all firms) & 5.2 & 5.5 \\
Share of employees with fixed-term contracts (basis: firms with fixed-term con- & 13.9 & 13.8 \\
tracts) & 2.5 & 3.3 \\
Enterprises with agency work contracts & 0.1 & 0.2 \\
Share of employees with agency work contracts (basis: all firms) & 6.2 \\
Share of employees with agency work contracts (basis: firms with fixed-term con- & 5.1 \\
tracts) & 84.1 & 87.2 \\
Share of firms hiring workers & 42.5 & 44.2 \\
Thereof share of firms with & 2.9 & 3.8 \\
- fixed-term contracts & 17.9 & 16.9 \\
- agency work contracts & 21.1 & 19.7 \\
Share hiring of employees (basis: all firms) & 25.3 & 23.5 \\
Share hiring of employees (basis: firms with fixed-term contracts) & \\
Share hiring of employees (basis: firms with agency work contracts)
\end{tabular}

Source: Russian enterprises survey, (RES, 2010).

7. Data for the 10 months of current year. 
The shares of employees with non-standard labour contracts are of course higher if only enterprises which use such contracts are considered. In 2010 the average percentage value of employees working under the conditions of fixed terms at enterprises using fixed-term labour contracts, was equal to $14 \%$ of the total number of employees. Enterprises using agency work contracts had 6.2\% of employees of the general staff number working on the basis of these contracts. It therefore seems that there are fixed costs involved when using non-standard wage contracts. Consequently, companies either do not use such contracts or they use them quite more intensively.

The evolution over time for both types of non-standard labour contracts was significantly different in 2009-10. While in 2010 the share of employees working at enterprises on the basis of fixed-term labour contracts stayed about constant, the number of employees with agency work contracts increased from $5.1 \%$ to $6.2 \%$ (Table 1 ).

\section{The description of enterprises using non-standard contracts}

Enterprises using non-standard labour contracts differ from others by branch, size and ownership. The highest share of enterprises using fixed-term labour contracts belongs to the extractive sector (more than 50\%), to manufacturing industry (45\%) and to the construction sector $(40 \%)$. Moreover, the share of employees with fixed-term labour contracts is highest in construction $(25 \%)$ and trade (17\%). Hence, construction is a sector where fixed-term labour contracts are not only more often used by enterprises but on average involve also more employees with such contracts per enterprise. It can be explained by the seasonal or project type of jobs carried out in this sector which results in fixed-term employment. Trade is affected by a seasonal factor as well. Furthermore, the sales volumes depend on the customer demand which is changing with the business cycle. Recruiting employees for a specified period of time makes the adjustment to seasonal and cyclical fluctuation easier for an enterprise. The increasing use of non-standard labour contracts could also signal a change in the application of the rule of law on the labour market.

Especially the early years of transition from the Socialist system to a contract based, market economy system were plagued by severe deficiencies, like wage arrears or other violations of contracts (Earle and Sabirianova Peter, 2004). During the recent crisis period enterprises instead used more standard mechanisms of reducing an employed excess supply of labour. It could very well be that this experience was quite expensive because of severance pay obligations and dispute settlements in courts. This experience could therefore have provided a boost to the perceived attractions of non-standard labour contracts.

Contrary to Russia, in Germany non-standard labour contracts are mainly used in the services sector (Hohendanner, 2010). Until 2008 only 12,8\% of all employees with temporary work contracts were employed in manufacturing industries, but 20,6\% worked in market services and $36.5 \%$ in social services (health care, welfare, education, public administration, non-profit services. In 2008-09 temporary work in these industries increased further and partly compensated the reduction of such work contracts in manufacturing industries.

The branch distribution of enterprises using agency work contracts is rather different. In 2010 such kind of labour contracts was mostly used in transport and communication enterprises (5.1\%), trade companies (4.3\%) and in the manufacturing industry (3.8\%). Moreover, the highest share of employees recruited under the terms of these contracts was found in the trade sector $(7 \%)$. Thus, trade is a sector where on the one hand enterprises use agency work contracts more often and on the other hand recruit more employees on this basis. One of the explanations of this phenomenon is that trading companies often use a network structure and it helps them to recruit 
employees from national and regional labour markets for a fixed period of time. The sectoral structure of agency work is different in Germany. $16 \%$ of all German firms in manufacturing industries use agency work contracts (IAB, 2009). $42 \%$ of all lease workers are employed in manufacturing industries (Bellmann, 2012).

However, not only the sector of economy but also the size, the ownership structure, the age of an enterprise matter for the utilization of non-standard labour contracts. In general, nonstandard labour contracts are more often used by large-scale and middle-scale enterprises than by small companies and they are most found in state enterprises (state ownership at least 50\%). There are two explanations for this: On the one hand, the choice of non-standard labour contracts is connected with restructuring processes which concern mostly old, large and middle scale enterprises which are still in state property. On the other hand, large and middle scale enterprises are very often characterized by over-employment which is inherited by them from Soviet times. If such firms have specific labour demands they hesitate to hire on standard labour contracts, because of higher separation costs. Mass layoffs are not an accessible option because of political pressures and high firing costs. These enterprises use fixed-term labour contracts and agency workers to react to demand fluctuations while maintaining profitability. Non-standard labour costs have the advantage of low separation costs and allow companies to restructure without immediately having to commit to long-term employment contracts.

\section{The differences of the personnel structure of enterprises depending on the contract form}

Heterogeneity tests in the framework of variance analysis allows the identification of significant staff differences between enterprises using non-standard labour contracts from those which do not use them.

The applied variance analysis resulted in the rejection of homogeneity with respect to the form of the labour contract for types of workers, which can be easily substituted (less-skilled employees of prevalent professions, young people, preretirement or retirement age workers and employees of entry level jobs).

A significant heterogeneity of the staff was not confirmed for all types of labour contracts and worker or firm characteristics. Staff differences of enterprises using agency work contracts proved to be insignificant by the overwhelming majority of factors analyzed. On the one hand, the small number of enterprises using this type of contracts could distort the test results. As is generally known, small groups are always more homogeneous comparing them with big ones. On the other hand, it could be that enterprises do not change the personnel structure by agency work procedures.

However, for companies with fixed term contracts significant heterogeneity can be found for a number of common characteristics. Enterprises with fixed-term labour contracts differ from others by employees' age structure. A lower share $(29 \%)$ of young workers employed at enterprises with fixed-term labour contracts than at enterprises with standard employment (32\%). At the same time enterprises with fixed-term labour contracts had more employees of preretirement and retirement age (13\%), i.e. older than 56, than other enterprises (9\%). Thus, enterprises with fixed-term labour contracts employed significantly more aged and less young employees than enterprises using only standard labour contracts. It is logical that the share of employees with a length of service of less than 1 year (19\%) was higher at enterprises with fixed-term labour contracts than at those which did not use them (16\%). 
Age and personnel experience structure at enterprises using agency work contracts did not significantly differ from other enterprises. All age and length of service groups were proportionally identical to those of other Russian enterprises.

Another significantly different factor concerns the level of education. It is widely known (Lancker, 2012; Casquel and Cunyat, 2011), that non-standard labour contracts are mostly used for less qualified employees, who are more often recruited for relatively simple operations and (or) for supporting work functions and occupy mostly entry level jobs, etc. Thus, we expect that enterprises with non-standard labour contracts employ more low-qualified employees than other enterprises where the job pattern demands a higher level of education and (or) on-the-job training.

This hypothesis is confirmed by results of the variance analysis. At enterprises with fixedterm labour contracts the number of low-qualified employees with only general secondary education (including incomplete secondary education) was higher (16\%) comparing it with other enterprises $(10 \%)$. At the same time enterprises with fixed-term labour contracts had less employees with higher education (40\%) comparing it with enterprises not using such kind of contracts $(45 \%)$.

The level of education is closely connected with an employee's occupation at an enterprise. We distinguish (according to the questionnaire data) three occupation levels. They included factory (office) workers carrying out simple works, specialists and managers. We expect that the share of employees recruited for jobs with low skill requirements should be higher at enterprises with non-standard labour contracts. At the same time low-qualified jobs will be presented by a relatively lower volume at all other enterprises. This reasoning is confirmed empirically. Enterprises with fixed-term labour contracts possessed a higher percentage value of workers (56\%) but a lower value of specialists with higher education (29\%) than it was observed at other enterprises not using fixed-term labour contracts (49\% an $34 \%$ accordingly).

There were no significant differences of qualification levels and profession-occupation structures found for enterprises with agency work contracts and other enterprises. Enterprises with agency work contracts did not differ from other enterprises by these features. Again, this could be the case because of the still low number of enterprises using agency work contracts.

The next factor which characterized the difference of enterprises with non-standard labour contracts from other enterprises was a gender structure. It is generally known, that in Russia "fixed-term employment was more characteristic for men than for women" (Gimpelson and Kapeliushnikov, 2006). The results of the present analysis also provide the indirect confirmation of this hypothesis. The percentage value of women at enterprises with fixed-term labour contracts is significantly lower (39\%) than at other enterprises (42\%). This allows the conclusion that the opportunity of fix-term employment at enterprises with fix-term labour contracts was less widespread for women than for men. One exception is the group of women of retirement age, who are significantly more employed in enterprises with fixed term contracts $(22 \%)$ than other enterprises $(18 \%)$.

Enterprises using agency work contracts have a different employee's gender structure. The percentage value of women at these enterprises was in general similar to that of other enterprises but differing from them by age structure. Enterprises with agency work contracts employed more young women of under 30 (42\%), than other enterprises (30\%). The enterprise workforce heterogeneity by women age structure was most apparent for a category of workers: low-qualified women hired into simple unskilled jobs at the very low occupational level. 
On the one hand, the larger share of young women employed on the basis of agency work contracts can be explained by double obligations with housekeeping and children that makes this kind of employment relatively attractive allowing them to have a flexible job schedule. On the other hand, we have no evidence that women voluntarily choose this type of employment. Enterprises may hesitate to employ young women on standard work contracts, because of the risk of costs associated with pregnancy and child caring obligations.

Furthermore, the high level of young women employed at enterprises using agency work contracts $(42 \%)$ can also be explained by their majority in trade and service sectors that include most of enterprises with agency work contracts. Many young women are employed in retail trade, which is the sector with an above average use of agency work contracts.

\section{Determinants of non-standard labour contracts}

A Probit analysis was performed to determine reasons which characterize differences between enterprises using non-standard labour contracts. On the one hand, this analysis should determine what appears to make the use of non-standard contracts more likely. On the other hand, these factors can illustrate requirements and capabilities of enterprises to increase their flexibility on the domestic labour market.

Note that all estimated coefficients presented in the following are informative only with regard to the sign and statistical significance of the effects, but not with regard to the magnitudes.

Moreover, we want to find out whether the two types of non-standard labour contracts (fixed term work and agency work) perform either as substitutes or as complements. As all types of non-standard labour contracts are limited in time, i.e. they actually appear as fixed-term contracts, they may bring similar costs and benefits for enterprises, which use such contracts. If from the point of enterprise view benefits and costs are similar for each type of labour contract, it is equally likely that an enterprise uses either contract and therefore one type of non-standard labour contract can be substituted by another. In this case, it does not make any difference for enterprises what type of non-standard labour contract to use and then these contracts perform as substitutes.

However, in the case of differences in user benefits and costs for some types of non-standard labour contracts it can be expected that enterprises will use specified types of non-standard labour contracts to solve different problems. Thereupon the two types of non-standard labour contracts can complement each other with respect to enterprise objectives.

If non-standard labour contracts perform as complements, the utilization of what type of non-standard labour contract will increase the probability of other type's utilization. Will this connection between non-standard labour contracts be unilateral or bilateral? In particular, if it is possible to assume that the utilization of fixed-term labour contracts will increase the probability of agency work contracts application and vice versa.

The Probit analysis results demonstrate that the utilization of fixed-term labour contracts and agency work contracts have both similarities and differences (Tables 2 and 3). A list of variables with basic descriptions is provided in the Annex Table.

The general property of these two types of non-standard labour contracts is their frequent simultaneous utilization at the same enterprises and in the same sectors of economy. In particular, both types of non-standard labour contracts are more often used at middle and large-scale indus- 
trial enterprises which as a rule are relatively old. These enterprises are very often characterized by staff redundancy and usually need restructuring and modernization.

Table 2. Fixed-term labour contracts determinants

\begin{tabular}{|c|c|c|}
\hline \multirow[b]{2}{*}{ Indicators } & \multicolumn{2}{|c|}{ Probit } \\
\hline & Coef. & $\begin{array}{l}\text { Std. } \\
\text { Err. }\end{array}$ \\
\hline Agency work contracts & 0.11 & 0.50 \\
\hline The proportion of women & $-0.98^{* \star *}$ & 0.31 \\
\hline Changes in organizational structure (1=yes) & $0.31^{\star *}$ & 0.14 \\
\hline The number of applied organizational technology & $0.09^{* *}$ & 0.04 \\
\hline \multicolumn{3}{|l|}{ Size (relative to $50-100$ employees) } \\
\hline The size of the enterprise (101-250) & 0.18 & 0.17 \\
\hline The size of the enterprise $(251-500)$ & 0.28 & 0.21 \\
\hline The size of the enterprise $(501-1000)$ & $0.46^{*}$ & 0.27 \\
\hline The size of the enterprise $(>1001)$ & $0.91^{* * *}$ & 0.29 \\
\hline Innovation in 2009-2010 (1=yes) & $0.31^{\star *}$ & 0.15 \\
\hline \multicolumn{3}{|l|}{ Investment (relative to non investment) } \\
\hline Minor investments & -0.23 & 0.16 \\
\hline Major investments & -0.15 & 0.18 \\
\hline $\begin{array}{l}\text { The company is organised according to structural principles (products or services) } \\
\text { (1=yes) }\end{array}$ & $-0.27^{\star *}$ & 0.13 \\
\hline Technical and technological level (1=very low; $5=$ high) & $-0.12^{* *}$ & 0.05 \\
\hline Presence of trade unions ( $1=y e s)$ & $0.31^{*}$ & 0.17 \\
\hline \multicolumn{3}{|l|}{ The size of the town (relative $>1$ million) } \\
\hline The size of the town (500 000-1 million residents) & $0.34^{* *}$ & 0.15 \\
\hline The size of the town $(100000-500000)$ & 0.11 & 0.22 \\
\hline The size of the town $(<100000)$ & $0.45^{\star}$ & 0.24 \\
\hline \multicolumn{3}{|l|}{ Sectors (relative to manufacturing) } \\
\hline Mining & -0.06 & 0.25 \\
\hline Construction & -0.08 & 0.20 \\
\hline Trade & $-0.36^{*}$ & 0.21 \\
\hline Transport and communications & $-0.36^{*}$ & 0.20 \\
\hline Finance & 0.06 & 0.24 \\
\hline Constant & -0.15 & 0.29 \\
\hline $\mathrm{N}$ & 497 & \\
\hline Pseudo R2 & 0.17 & \\
\hline
\end{tabular}

Note: Levels of significance: ${ }^{*}-10 \% ;{ }^{* *}-5 \% ;{ }^{* \star}-1 \%$.

Companies with a large share of female workers tend to use less temporary work contracts, although a-priori a positive relationship (as formulated in Hypothesis 10) seems to be more reasonable, as female workers have a higher rate of absence, which usually is filled with nonstandard work contracts. One explanation could be that segregation on the Russian labour market differentiates between "male" and "female" workplaces (Malzeva and Roschin, 2006). Industries such as manufacturing, construction and transport are more popular among males while most part of employed women is engaged in the public sector and trade (Karabchuk, 2012). The gender gap in the probability of temporary employment could be explained by educational differences and qualification segregation. About $57 \%$ of employed males take low qualified positions, while only $27 \%$ of employed females are concentrated here (Karabchuk, 2012). Men are more likely to be- 
come temporary workers in Russia as they have generally a lower level of education and lower professional qualifications than women. In addition, temporary (fixed term) employment in Russia was always higher for men than for women (Gimpelson and Kapeliushnikov, 2006).

Table 3. Determinants of agency work contracts

\begin{tabular}{|c|c|c|}
\hline \multirow{2}{*}{ Indicators } & \multicolumn{2}{|c|}{ Probit } \\
\hline & Coef. & Std. Err. \\
\hline Fixed-term contract & $0.01^{* * *}$ & 0.00 \\
\hline Technical and technological level ( $1=$ very low; $5=$ high) & $0.28^{* *}$ & 0.12 \\
\hline Outsourcing of marginal activities in 2009 & $0.97^{* * *}$ & 0.31 \\
\hline A good financial situation in 2010 (1=yes) & $0.61^{\star *}$ & 0.24 \\
\hline Improving the financial situation in 2010 relative to 2009 (1=yes) & $-0.63^{\star *}$ & 0.26 \\
\hline The size of the enterprise $(<100$ workers $=1)$ & $-0.65^{\star *}$ & 0.33 \\
\hline CIS Market $(1=$ yes $)$ & $0.64^{* *}$ & 0.27 \\
\hline Age of enterprise & $0.01^{*}$ & 0.00 \\
\hline \multicolumn{3}{|l|}{ Size of the town (relative to $>1$ million) } \\
\hline The size of the town (500 000-1 million residents) & -0.30 & 0.30 \\
\hline The size of the town $(100000-500000)$ & -0.33 & 0.41 \\
\hline The size of the town $(<100000)$ & -0.22 & 0.45 \\
\hline Regions (Moscow, Saint-Petersburg=1) & -0.15 & 0.36 \\
\hline \multicolumn{3}{|l|}{ Sectors (relative to mining) } \\
\hline Manufacturing & 0.30 & 0.36 \\
\hline Construction & 0.04 & 0.59 \\
\hline Trade & 0.63 & 0.48 \\
\hline Transport and communications & $0.74^{*}$ & 0.42 \\
\hline Finance & -0.27 & 0.57 \\
\hline Constant & $-4.01^{* * *}$ & 0.73 \\
\hline $\mathrm{N}$ & 721 & \\
\hline Pseudo R2 & 0.31 & \\
\hline
\end{tabular}

Note: Levels of significance: ${ }^{*}-10 \%{ }^{* \star}-5 \% ;{ }^{* \star}-1 \%$.

It was also found that if enterprises already use fixed-term labour contracts there is a significant probability that they will use agency work contracts as well. This cannot be found for agency work contracts the other way round. The utilization of these contracts does not increase the probability of fixed-term labour contracts application. Thus, the relationship between these two types of non-standard labour contracts appears to be complementary.

It may be explained by the difference of benefits obtained by enterprises from each type of non-standard labour contracts. Moreover, to be more precise we may speak about costs savings which will be different when using two types of these contracts. If fixed-term labour contracts allow an enterprise to realize "point" saving by transferring some employees' jobs under the conditions of fixed-term labour contracts, agency work contracts provide a possibility for an enterprise to obtain "mass" saving, i.e. to decrease costs owing to the larger quantity of employees, transferring some departments and business units under the conditions of agency work contracts.

At the same time the utilization of non-standard labour contracts by enterprises has its own differences. They lie in the differences of the application of non-standard labour contracts with respect to sectors of the economy and types of enterprises. For example, fixed-term labour contracts were more often used in extractive and construction sectors of economy and agency work 
contracts were more typical for transport, communication and trade sectors. At the same time transport, communication and trade sectors which used agency work contracts quite often had a low probability of fixed-term labour contracts utilization for their employees. Moreover, if enterprises operated on the basis of labour specialization by types of products, i.e. typical for commercial companies, they used less fixed-term labour contracts but more often used agency work contracts.

The next difference is that fixed-term labour contracts are more often used by large-scale enterprises (more than 500 people) but agency work contracts were more typical for middle-scale enterprises (from 100 up to 500 people). Though, in general enterprise size and the probability of both types of non-standard labour contracts go hand in hand. We expect that the utilization of non-standard labour contracts at enterprises accompanied their restructuring processes.

As the utilization of fixed-term labour contracts was found to be affected by enterprise size, they were very often associated with trade unions presence. Large-scale enterprises have more numerous and powerful trade unions. Since fixed-term labour contracts were more often used at large-scale enterprises so they were mostly enterprises with active trade unions.

At the same time, it can also be explained in a different way. On the one hand, trade unions always opposed the utilization of agency work labour contracts and were less hostile to fixed-term labour contracts as the latter did not "destroy" the traditional employment relationship between employers and employees. On the other hand, fixed-term labour contracts provided a possibility for trade unions to protect incumbent employees (and trade union members) from dismissal. Thus the subdivision of employees into insiders (with standard labour contracts) and outsiders (with fixed-term labour contracts) was in complete correspondence with trade unions policy to protect their members. In line with all these observations the share of fixed -a term labour contract at enterprises with trade unions was found to be rather high.

The utilization of non-standard labour contracts differs also by ownership. Both types of non-standard labour contracts were more often used at state enterprises. However, they were also quite often used at enterprises of other types of property. So, fixed-term labour contracts were mostly used at private enterprises with foreign capital and agency work contracts at private Russian enterprises.

Enterprises age factor also plays a role. Enterprises with fixed-term labour contracts are older than those using agency work contracts. And this is quite reasonable. On the one hand, the oldest enterprises in Russian market are mostly large-scale state-owned enterprises which more often use fixed-term labour contracts. On the other hand, fixed-term labour contracts started to be used by enterprises much earlier than agency work contracts. The latter appeared in Russian labour market in the mid 1990's and started to be used by Russian enterprises only at the end of the 1990's. Earlier, agency work contracts were used only by enterprises with foreign capital. Most of Russian private enterprises were established after the emergence of agency work contracts into Russian market. Thus, enterprises with agency work contracts proved to be on average younger than those with fixed-term labour contracts.

At the same time, organizational and financial-economic factors also affected positively the utilization probability of fixed-term labour contracts by enterprises. Thus, corporate restructuring was more intensive and frequent at enterprises with fixed-term labour contracts. And in particular, it included the change of the organizational structure; business processes restructuring, benchmarking operations, the development of employees' career plans, etc. 
Moreover, different kinds of innovations were also realized at enterprises with fixed-term labour contracts (Table 2). Technological advancements, new types of product development, research and development activities were performed at these enterprises. All these processes in the course of time made it necessary either to decrease the number of employees or to increase the flexibility of their employment making some part of the staff to work on a fixed-term contract basis.

On the one hand, both non-standard labour contracts corresponded to the general enterprise strategy of cost decrease. On the other hand, enterprises preferred only one of two strategies that is a flexible labour force. It is likely that the high costs of dismissal provides incentives for firms to use more flexible employment contracts (Gimpelson, Kapeliushnikov, 2006).

Therefore, the stability of employment relation decreased alongside with some employees having to accept more flexible work contracts, which improves conditions for employees selection. Thus, in the course of restructuring only the most productive employees continued to work at these enterprises.

At the same time if enterprises had a more advanced level of technology and engineering comparing it with the average branch level, i.e. possessed advanced, more productive modern equipment and facilities, etc., they used fixed-term labour contracts with less probability (Table 2 ). On the contrary, they used agency work contracts more often (Table 3 ).

Probably this type of enterprises included monopolies, transport and communication enterprises and (or) enterprises of large trade networks. Their financial status was relatively stable in 2010 comparing it with other enterprises and they operated on CIS markets. They used agency work contracts for their cost savings. The demand for such kind of labour contracts increased during periods of economic crisis. However, with the improvement of the financial status of an enterprises (in 2010 comparing it with 2009), the demand for agency work contracts decreased again.

If enterprises used outsourcing, they usually recruited employees on the basis of agency work contracts (Table 3). However, it also happens that employees are transferred to outsourcing, especially in large restructuring holding companies, which establish small "competence pools" in order to establish an internal labour market ${ }^{8}$ Such phenomena point at the perceived restrictiveness of the Russian labour code together with a broader implementation of existing regulation. In other words, a broadening "rule of law" makes restrictions in existing legislation more binding and therefore provides incentives to find legal ways around these restrictions.

Fixed-term labour contracts and agency work contracts also differ in terms of gender. The number of women at enterprises with fixed-term labour contracts was lower (39\%) than at enterprises not using such contracts. On the contrary, it was higher at enterprises with agency work contracts $(45 \%)$. At the same time the probability of using fixed-term labour contracts decreases with an increasing share of women in the labour force. This phenomenon differentiates the Russian labour market from other countries and can be explained by several reasons.

First of all enterprises with fixed-term labour contracts active mostly in "male" sectors (construction, extraction sectors), and consequently, they employ more men than women. The average percentage value of women in extraction sectors was equal to $28 \%$, in construction industry $26 \%$.

8. In Germany this has become known as "Konzernleihe" (labour lease within an enterprise conglomerate). See Kohaut, Lehmer et al., 2009 
Secondly, fixed-term labour contracts have a close connection with lower working place quality, in particular employment instability. They are more often used for working places with a higher probability of staff reduction characterizing their low quality. This type of working places is characteristic for old economic sectors (industry, construction, extraction sectors). It is generally known, that in Russian labour market women are more often recruited for working places with a high degree of protection (education, health care service, etc.) which decreases the probability of their employment in sectors with the high number of fixed-term labour contracts.

Thirdly, women's salary is as a rule lower than that of $\operatorname{men}^{9}$. Thereupon, the dismissal of women working under conditions of standard labour contracts would be accompanied with lower costs for an enterprise (with other costs being equal) than dismissal of a man. To decrease dismissal costs enterprises usually replace highly-paid employees, who were mostly represented by men, by fixed-term labour contracts.

Considering the fact that women are usually busy with their own household, the increase of their share in the total number of employees should increase the probability of fixed-term labour contracts utilization by enterprises. However, it did not take place in Russia due to the fact that enterprises with fixed-term labour contracts were concentrated in sectors of economy with a low number of female employees. Thus, fixed-term labour contracts function as a substitution for high costs of male employees.

The number of women at enterprises using agency work contracts was higher (45\%) than it was at enterprises which did not use them (40\%). It was mostly notable for trade companies, where the share of women in the total number of employees was maximum high (51\%). At the same time, the salary level at these enterprises increases with the share of the female labour force. In 2010 the average monthly salary at enterprises where the number of female employees was above $50 \%$ of the total number of employees, was higher (RUB 21.000) than at enterprises where the share of woman was lower than 50\% (RUB 18.000).

Trade belongs to the sectors of economy where the volume of agency work contracts is high comparing it with other sectors. Moreover, the average monthly salary level there is one of the highest. Thus, a higher share of women at enterprises with a high salary level increases the probability of the substitution of their working places by agency work contracts. It confirms once again the conclusion that non-standard labour contracts, and in this case agency work contracts, are used by enterprises with a relatively high salary level for decreasing their costs and in particular their dismissal costs.

One more difference of these two types of non-standard labour contracts was influenced by the development of market infrastructure and in particular by the development of employment service suppliers at the labour market (search of employees, their selection, training, and manpower records management, etc.). An insufficient development of such market services, including labour market service, observed in the outlying regions far from the centre and in small cities (with the population of less than 1 million people) negatively affected the utilization of agency work contracts by enterprises. Agency work contracts are more often used by enterprises in big cities while fixed-term labour contracts are more typical for enterprises located in cities with the population of less than 1 million.

9. An estimate of the gender wage gap, controlled for sectoral, regional, skill and education factors is provided by Smirnykh - Wörgötter, 2001 and amounts to about $25 \%$. 
As it was already noted Russian enterprises want to expand the use of agency work contracts, decreasing at same time the utilization of fixed-term labour contracts. Following these assumptions the most intensive increase of agency work contracts is forecasted in industry and construction at middle-scale enterprises (100-250 people) of private ownership.

\section{Non-standard labour contracts and Worker Flows}

Non-standard labour contracts can play a positive role in economy if they increase the employment level. In other words, their utilization by enterprises can promote general job growth in the economy.

However, the increased recruiting of employees at some enterprises can be accompanied with a high level of dismissals. In this case, job growth is possible not to occur. If levels of recruiting and dismissals are equal job growth will not take place, employees' mobility will increase but the stability of employment relationship will decrease on the enterprise level.

The gross manpower turnover ${ }^{10}$ and net changes of employment ${ }^{11}$ serve as factors used for stability (mobility) appraisal and for the employment level change at enterprises. These indicators are calculated by the determination of shares for recruited and dismissed employees on the average staff number within the specific period of time. The comparison of recruiting and dismissal shares and also the gross manpower turnover and employment net changes for several groups of enterprises provides the possibility to appraise the dependence of employment increase (decrease) on the utilization of non-standard labour contracts.

Research results demonstrate that enterprises with non-standard labour contracts recruited more employees than those which did not use this type of contracts. Thus, the recruiting value in the average number of employees at enterprises with fixed-term labour contracts was equal to $8 \%$ in 2009 increasing up to $19 \%$ in 2010, whereas it remained on the level of 13\% in 2009-10 at enterprises with standard labour contracts. The number of recruiting employees was even higher at enterprises using agency work contracts. It was equal to $21 \%$ of the average number of employees in 2009 and increased up to $23 \%$ in 2010 . Thus, enterprises using agency work contracts increased employment by about one fifth during the crisis and periods immediately afterwards. It was almost twice as much than the recruiting value of enterprises with standard labour contracts and 3-5 percentage points higher than at enterprises with fixed-term labour contracts.

However, not only the recruiting level was higher at enterprises with non-standard labour contracts but the dismissal level was higher as well. In 2009 the maximum level of dismissals (20\%) was observed at enterprises with fixed-term labour contracts. They were followed by enterprises with agency work contracts (17\%). The dismissal level (13\%) at enterprises with standard labour contracts was relatively lower during the crisis period.

Most of enterprises decreased the number of dismissals in 2010. Enterprises with fixed-term labour contracts decreased the dismissal share to $18 \%$ and enterprises with standard labour contracts decreased it to $11 \%$ of the average number of employees.

10. The gross manpower turnover is equal to the sum of recruiting and dismissal shares in the average number of employees.

11. The value of employment net changes is calculated as the difference between recruiting and dismissal shares in the average number of employees at enterprises. 
Against the general background of dismissal decrease only enterprises with agency work contracts were the exception in this process. In 2010 they increased the dismissal share (20\%) comparing it with the previous period. It took place rather not because of the further decline of their economic status but due to the increase of recently recruited employees share including the outsourcing of employees.

Thus with high levels of employees' recruiting and dismissal activities a decrease of the stability of employment relationship took place at enterprises with non-standard labour contracts. As recruiting and dismissal values were maximum high at these enterprises, they covered a higher number of employees comparing it with other enterprises. Thus, a large quantity of employees had unstable employment at enterprises with non-standard labour contracts both within the crisis (2009) and afterwards (2010).

Table 4. Worker Flows and Employment Dynamic at enterprises with different types of labour contracts

\begin{tabular}{|c|c|c|c|c|c|c|}
\hline & $\begin{array}{c}\text { Temporary Work } \\
\text { Contracts }\end{array}$ & $\begin{array}{c}\text { Mean } \\
\text { (Std. dev.) }\end{array}$ & F-test & $\begin{array}{l}\text { Agency Work } \\
\text { Contracts }\end{array}$ & Mean & F-test \\
\hline \multirow[t]{2}{*}{ Hiring } & No & $\begin{array}{l}0,13 \\
(0,16)\end{array}$ & \multirow[t]{2}{*}{$25,21^{\star \star \star}$} & No & $\begin{array}{l}0,15 \\
(0,16)\end{array}$ & \multirow[t]{2}{*}{$7,94^{* \star}$} \\
\hline & Yes & $\begin{array}{l}0,19 \\
(0,17)\end{array}$ & & Yes & $\begin{array}{l}0,23 \\
(0,21)\end{array}$ & \\
\hline \multirow[t]{2}{*}{ Firing } & No & $\begin{array}{l}0,11 \\
(0,15)\end{array}$ & \multirow[t]{2}{*}{$31,27^{\star \star *}$} & No & $\begin{array}{l}0,13 \\
(0,15)\end{array}$ & \multirow[t]{2}{*}{$6,45^{\star \star}$} \\
\hline & Yes & $\begin{array}{l}0,17 \\
(0,16)\end{array}$ & & Yes & $\begin{array}{l}0,20 \\
(0,19)\end{array}$ & \\
\hline \multirow[t]{2}{*}{ Turnover } & No & $\begin{array}{l}0,24 \\
(0,28)\end{array}$ & \multirow[t]{2}{*}{$31,77^{\star * *}$} & No & $\begin{array}{l}0,28 \\
(0,29)\end{array}$ & \multirow[t]{2}{*}{$9,33^{\star \star \star}$} \\
\hline & Yes & $\begin{array}{l}0,36 \\
(0,30)\end{array}$ & & Yes & $\begin{array}{l}0,44 \\
(0,37)\end{array}$ & \\
\hline \multirow[t]{2}{*}{$\begin{array}{l}\text { Net change of } \\
\text { employment }\end{array}$} & No & $\begin{array}{l}0,02 \\
(0,12)\end{array}$ & \multirow[t]{2}{*}{0,81} & No & $\begin{array}{l}0,02 \\
(0,13)\end{array}$ & \multirow[t]{2}{*}{0,62} \\
\hline & Yes & $\begin{array}{l}0,02 \\
(0,14)\end{array}$ & & Yes & $\begin{array}{l}0,04 \\
(0,17)\end{array}$ & \\
\hline \multirow[t]{2}{*}{ Wage level } & No & $\begin{array}{l}18173,03 \\
(9551,80)\end{array}$ & \multirow[t]{2}{*}{0,00} & No & $\begin{array}{l}18126,48 \\
(8807,84)\end{array}$ & \multirow[t]{2}{*}{2,23} \\
\hline & Yes & $\begin{array}{l}18157,00 \\
(7650,88)\end{array}$ & & Yes & $\begin{array}{l}21104,17 \\
(7947,44)\end{array}$ & \\
\hline \multirow[t]{2}{*}{$\begin{array}{l}\text { Wage change } \\
(2010-2009)\end{array}$} & No & $\begin{array}{l}+564,07 \\
(4321,55)\end{array}$ & \multirow[t]{2}{*}{0,83} & No & $\begin{array}{l}+278,68 \\
(8487,30)\end{array}$ & \multirow[t]{2}{*}{0,21} \\
\hline & Yes & $\begin{array}{l}-60,78 \\
(12063,79)\end{array}$ & & Yes & $\begin{array}{l}+1148,20 \\
(2037,28)\end{array}$ & \\
\hline
\end{tabular}

Note: Levels of significance: ${ }^{*}-10 \% ;{ }^{* \star}-5 \% ;{ }^{* \star}-1 \%$.

This observation can be confirmed by the gross turnover factors (Table 4) as well. Enterprises with non-standard labour contracts had a higher factor of (0.36-0.37), than it was at enterprises not using such labour contracts (0.24-0.26) and the difference turns out to be significant. Moreover, if in 2009 the highest value of manpower turnover (higher than the average level) was found at enterprises with fixed-term labour contracts (0.38), in 2010 its maximum level (0.44) was observed at enterprises using agency work contracts. In other words the employment was most unstable at enterprises with fixed-term labour contracts in 2009 with agency work contracts in 2010 .

The employment instability simultaneously means higher mobility of employees. Judging by the factor of employment net changes the number of recruited and dismissed employees was ac- 
tually equal at enterprises (Table 4). As a result, the difference between recruiting and dismissal values was insignificant and employment net changes at enterprises were small. On the one hand, it provides an evidence of the fact that within the period of 2009-10 the model of "idle speed" with a recruiting share being actually equal to a dismissal share continued to operate on the Russian labour market. Thus, no significant employment increase occurred.

In 2009 employment decreased at most Russian enterprises, i.e. the dismissal level, though insignificantly, exceeded the recruiting level. Only enterprises using agency-work contracts were an exception.

The employment increase began to show at all enterprises in 2010 when the economic situation improved. Moreover, the employment increase at enterprises with agency work labour contracts was twice as high in comparison with other enterprises.

Thus, non-standard labour contracts did not promote an employment increase at Russian enterprises but they kept the employment on a fixed level due to the increase of employment flexibility for some categories of employees. The increased flexibility on the labour market resulted in the suppression of unemployment growth, which in general can be considered as a positive contribution of non-standard labour contracts to economy.

\section{Summary}

The number of enterprises using non-standard labour contracts and the number of employees involved into non-standard labour relationship increased on the Russian labour market in 2009-10. Non-standard labour contracts are concentrated in particular types of enterprises. Moreover, various forms of non-standard labour contracts are rather complements than substitutes. The probability of agency-work contracts increases in enterprises that use fixed-term labour contracts.

In general, agency-work contracts were used by a small number of enterprises but had a very high rate of growth. Fixed-term labour contracts were more popular than agency-work contracts though the share of enterprises and the number of employees with fixed-term labour contracts had a low rate of growth.

The staff composition at enterprises with non-standard labour contracts is different from enterprises not using this type of contracts. Enterprises used non-standard labour contracts to obtain flexibility. In this case, they formed "a buffer" with the staff composition differing depending on the type of labour contract used.

The "buffer" at enterprises with fixed-term labour contracts was formed mostly by male, low qualification employees and by pre-retirement and retirement age employees. The "buffer" at enterprises with agency-work contracts comprised mostly young women, who occupied low positions and possessed a low qualification level. Moreover, the age structure of female employees at enterprises with fixed-term labour contracts differs from enterprises with agency-work contracts. Enterprises with fixed-term labour contracts employed more women of retirement age and those with agency-work contracts recruited more young women under 30.

Manufacturing industries use both fixed term and agency work contracts. In addition, fixed term work is more widespread in construction and extractive industries, while agency work is more used in retail trade, transport and communications. 
Companies with non-standard labour contracts are more often medium sized to large, old and in public ownership. In companies with restructuring needs fixed term contracts are more likely. Companies using agency work are profitable and export to CIS markets. Fixed term employment is less likely in companies with a higher technological level, while agency work is more widespread in companies with more specialized skill requirements. Companies with a high share of female employees use less fixed term work, which could be related to the higher risk aversion of women, who therefore join companies with more stable employment. Another explanation could be segregation of workplaces into "male" and "female" ones.

The results of analysis showed that in 2009-10 the "Russian model" (when hiring and layoffs are equal) of "idle speed" continued to function on the Russian market. Moreover, it functioned regardless of contract relationship with employees at enterprises. Thus, new contract forms increase labour turnover, but not net job creation.

At the same time, non-standard labour contracts had a "supporting" effect on the employment of the core workforce. Enterprises with non-standard labour contracts recruited more employees though also dismissing more of them. As a result, enterprises with non-standard labour contracts differed from others by two features. First of all, they were in general characterized by the high level of employees' mobility, by the low level of employment relationship stability and also by a more unstable employment relationship. Secondly, the segmentation of their internal labour markets was larger in scale than at enterprises with only standard labour contracts. Thus, enterprises with non-standard labour contracts "supported" the general level of employment on a relatively permanent level by decreasing the employment stability for marginal employees. Agency and temporary work generate a secondary segment of working places.

The increase of segmentation and the expansion of an unstable employment segment in internal markets of enterprises with non-standard labour contracts provide evidence of two important processes going on in Russian labour market. On the one hand, the secondary segment growth justifies the fact that Russian enterprises use it as complementary facility to increase the flexibility which helps them to adjust to varying demand conditions. On the other hand, the increase of unstable employment segment at Russian enterprises using non-standard labour contracts demonstrates the transformation of standard labour contracts for an increasing number of employees. It indicates the necessity to improve the Russian labour legislation, which is still mostly oriented to standard labour relations considering working conditions of employees and the employment character of the given "unstable" segment. 


\section{ANNEX A1. \\ DESCRIPTION OF VARIABLES}

\begin{tabular}{|c|c|}
\hline Agency work contracts & 1/0 dummy: 1 if enterprises have agency work contracts \\
\hline Fixed-term contracts & 1/0 dummy: 1 if enterprises have fixed-term contracts \\
\hline The proportion of women & Share of women in total employment \\
\hline $\begin{array}{l}\text { Changes in organizational } \\
\text { structure (1=yes) }\end{array}$ & $1 / 0$ dummy: $1=y e s$ if changes in organizational structure \\
\hline $\begin{array}{l}\text { The number of applied or- } \\
\text { ganizational technologies }\end{array}$ & $\begin{array}{l}\text { Number of measures for the development and modernisation of organisa- } \\
\text { tional and production processes }\end{array}$ \\
\hline The size of the enterprise & The size of the enterprise ( $<100$ workers $=1)$ \\
\hline Innovation in $2009-2010$ & $1 / 0$ dummy: $1=$ if an innovation in $2009-2010$ was implemented \\
\hline Investments volume & Investments volume (secondary investments $=1$ ) \\
\hline $\begin{array}{l}\text { The design principle of the } \\
\text { structural subdivisions = } \\
\text { product (service) }\end{array}$ & $\begin{array}{l}1 / 0 \text { dummy: } 1=\text { if the design principle of the of structural subdivisions is } \\
\text { product (service) }\end{array}$ \\
\hline $\begin{array}{l}\text { Technical and technological } \\
\text { level }\end{array}$ & $\begin{array}{l}\text { Technical and technological level of plant and equipment compared with } \\
\text { other companies in the same sector: } 1=\text { very low; } 5=\text { high }\end{array}$ \\
\hline There are trade unions & $1 / 0$ dummy: $1=$ if there are trade unions \\
\hline The size of the town & Volume of residents in the town $(\geq 1000000$ residents $=1)$ \\
\hline $\begin{array}{l}\text { Sectors: Industry, Construc- } \\
\text { tion, Trade, Mining, Trans- } \\
\text { port and communications, } \\
\text { Finance }\end{array}$ & $\begin{array}{l}\text { Sectors of the economy (industry }=1 \text { for fixed-term contracts regression), } \\
\text { (mining = } 1 \text { for agency work contracts regression) }\end{array}$ \\
\hline $\begin{array}{l}\text { Outsourcing of marginal } \\
\text { activities in } 2009\end{array}$ & $1 / 0$ dummy: $1=$ if there is Outsourcing in 2009 \\
\hline Financial situation in 2010 & $1 / 0$ dummy: $1=$ if the financial situation in 2010 is good \\
\hline $\begin{array}{l}\text { Financial situation in } 2010 \\
\text { compared with } 2009\end{array}$ & $\begin{array}{l}1 / 0 \text { dummy: } 1=\text { if the the financial situation in } 2010 \text { improved compared with } \\
2009\end{array}$ \\
\hline CIS Market & $1 / 0$ dummy: $1=$ if delivery of the products to CIS markets \\
\hline Age of enterprise & Age of enterprise, years \\
\hline Regions & Russian Regions (Moscow, St.Petersburg=1) \\
\hline
\end{tabular}




\section{BIBLIOGRAPHY}

Abraham, K. G. (1998), "Flexible staffing arrangements and employers short-term adjustment strategies", in Hart, R.A. (Hg.), Employment, unemployment and labor utilization, London, p. 288-311.

Abraham, K. G. and Taylor, S. K. (1996), Firms' Use of Outside Contractors: Theory and Evidence, Journal of Labor Economics, No. 14 (3), pp. 394-424.

Atkinson, J. (1987), "Flexibility or fragmentation? The United Kingdom labor market in the eighties", Labor and Society, 12 Jg., H. 1, pp. 87-105.

Autor, D. and Houseman, S. (2010), "Do Temporary Help Jobs Improve Labor Market Outcomes for Low-Skilled Workers? Evidence from "Work First"”, American Economic Journal: Applied Economics 2, 96-128.

Barmby, T. and Stephan, G. (2000), "Worker absenteeism: Why firm size matter", The Manchester School, 68 Jg., H. 5, pp. 568-577.

Bartelsman, E. J. and Hinloopen, J. (2005), "Unleashing animal spirits: ICT and economic growth", in L. Soete and B. ter Weel (eds.), The Economics of the Digital Economy, Edward Elgar Publising.

Bellmann, L. (2012), Statistische Daten zu befristeter Beschäftigung - Arbeitsmarktwirkungen. Vortrag beim Expertenworkshop zum Thema „Befristungsrecht“ des DGB und der Friedrich-Ebert Stiftung, Berlin, 26. January 2012, www.hugo-sinzheimerinsttut.de/fileadmin/user data hsi/ab 2011/Texte/Statistische Daten zu befristeter Besch aeftigung-Bellmann 2601121 .pdf.

Bellmann, L. and Alda, H. (2004), „Betriebliche Personal- und Beschäftigungspolitik zwischen Flexibilität und Stabilität“, in WSI Mitteilungen, H.5, s. 255-261.

Boeri, T. (2011), "Institutional Reforms and Dualism in European Labor Markets", in O. Ashenfelter and D. Card (eds.), Handbook of Labor Economics, pp. 1173-1236.

Boockmann, B. and Hagen, T. (2003), "Works councils and fixed-term employment: Evidence from West German establishments", in Schmollers Jahrbuch, 123, s. 359-381.

Boockmann, B. and Hagen, T. (2006), Befristete Beschäftigungsverhältnisse - Brücken in den Arbeitsmarkt oder Instrumente der Segmentierung?, Baden-Baden.

Booth, A.L., Francesconi, M. and Frank, J. (2002), "Labour as a buffer: Do temporary workers suffer?", IZA Discussion Papers, No. 673. 
Booth, A.L., Francesconi, M., Frank, J. (2002). Labor as a buffer: do temporary workers suffer? IZA Discussion Paper, N 673.

Brehmer, W. and Seifert H. (2009). Sind atypische Beschäftigungsverhältnisse prekär? Eine empirische Analyse sozialer Risiken, Zeitschrift für Arbeitsmarktforschung 4, s. 501 - 531.

Brinkmann, U., Dörre, K and Röbenack, S. (2006). Prekäre Arbeit. Ursachen, Ausmaß, soziale Folgen und subjektive Verarbeitungsformen unsicherer Beschäftigungsverhältnisse, Friedrich-Ebert-Stiftung (Hg.), Bonn.

Brodsky, M.M. (1994). Labor market flexibility: a changing international perspective. In: Monthly Labor Review, 117. Jg. H. 11, s. 53-60.

Capelli, P. and Neumark, D. (2001). External job churning and internal job flexibility. In: NBER Working Paper, No. 8111.

Cappellari, L., C. Dell. Aringa and Leonardi, M. (2011). Temporary Employment, Job Flows and Productivity: a Tale of Two Reforms., CESifo working paper No. 3520.

Cappelli, P. and Neumark, D. (2004), External churning and internal flexibility: evidence on the functional flexibility and core-periphery hypotheses, Industrial Relations, 43(1), 148-182.

Casouel, E. and Cunyat, A. (2011). Temporary Contracts, Employment Protection and Skill: an Application to Spain. The Manchester School, 79, p. 1237-1261.

Destatis, Statistisches Bundesamt (2008). Atypische Beschäftigung auf dem deutschen Arbeitsmarkt, Wiesbaden.

Dolado, J. J., Ortigueira, S. and Stucchi, R. (2012). Does Dual Employment Protection Affect TFP?: Evidence from Spanish Manufacturing Firms., CEPR Discussion Paper, No. 8763.

Dull, H. and Ellguth, P. (1999). Atypische Beschäftigung: Arbeit ohne betriebliche Interessenvertretung? Empirische Analysen mit dem IAB-Betriebspanel zum Einfluss von Betriebsräten auf befristete und geringfügige Beschäftigung. In: WSI Mitteilungen, 52. Jg., H. 3, s. 165176.

Earle, J.S., Sabirianova Peter, K. (2004). Contract Violations, Neighborhood Effects, and Wage Arrears in Russia. IZA Discussion Paper, No 1198; William Davidson Institute Working Paper, No 708.

Gensicke, M., Herzog-Stein, A., Seifert, H. and Tschersich, N. (2010). Einmal atypisch, immer atypisch beschäftigt? Mobilitätsprozesse atypischer und normaler Arbeitsverhältnisse im Vergleich, WSI-Mitteilungen 163, s. 179-187.

Gimpelson, V.E. and R.I. Kapelushnikov (eds.) (2006). Non-standard employment in the Russian economy, The Publishing House of NRU HSE, Moscow.

Gönenç, R. et al. (2012), "Structural Reforms to Boost Turkey's Long-Term Growth”, OECD Economics Department Working Papers, No. 987, OECD Publishing. 
Gundert, S. and Hohendanner, C. (2011). Leiharbeit und befristete Beschäftigung: Soziale Teilhabe ist eine Frage von stabilen Jobs, IAB-Kurzbericht, 4/2011, Nürnberg, Institut für Arbeitsmarkt-und Berufsforschung.

Hagen, T. and Boockmann, B. (2002). Determinanten der Nachfrage nach befristeten Verträgen, Leiharbeit und freier Mitarbeit, Empirische Analysen auf Basis des IAB-Betriebspanels. In: L. Bellmann \& A. Kölling (Hrsg.), Betrieblicher Wandel und Fachkräftebedarf, (Beiträge zur Arbeitsmarkt- und Berufsforschung, 257), Nürnberg, S. 199-235.

Heckman, J.J. (1979). Sample selection bias as a specification error. Econometrica, 47. Jg., H 1, pp. 153-161.

Hohendanner, C. (2010). Befristete Arbeitsverträge Zwischen Auf-und Abschwung. Unsichere Zeiten, Unsichere Verträge? IAB-Kurzbericht 14/2010, Nürnberg, Institut für Arbeitsmarkt-und Berufsforschung, online available at http://doku.iab.de/kurzber/2010/kb1410.pdf.

Hüfner, F. (2012), , OECD, Paris

Hüfner, F., Klein C. and Wörgötter, A. (2012). The German labour market in the great recession lessons for other countries, in Colombano - Shaw (2012), Re-Developing America, University of Pennsylvania Press, forthcoming.

Ichino, A. and Muehlheusser, G. (2004). How often should you open the door? Optimal monitoring to screen heterogeneous agents, IZA Discussions Paper, N. 385.

Ichino, A. and Riphahn, R. T. (2005). .The Effect of Employment Protection on Worker Effort: A Comparison of Absenteeism During and After Probation, Journal of the European Economic Association, 3(1), p. 120-143.

Ichino, A., Mealli, F., Nannicini, T. (2008). From Temporary Help Jobs to Permanent Employment: What Can We Learn from Matching Estimators and their Sensitivity?, Journal of Applied Econometrics, 23(3), p.305-327.

Jahn, E. (2010). Reassessing the wage penalty for temporary agency workers in Germany. Journal of Economics and Statistics 2, pp. 208-233.

Jahn, E. and Bentzen, J. (2010). What Drives the Demand for Temporary Agency Workers? IZA DP No. 5333.

Jahn, E., Riphahn, R. T., Schnabel, C. (2012). Flexible Forms of Employment: Boon and Bane, April 2012, LASER Discussion Papers, Paper No. 62.

Kalleberg, A.L. (2001), Organizing flexibility: the flexible firm in a new century, British Journal of Industrial Relations, 39(4), 479-504.

Kalleberg, Arne L. (2009). Presidential Address: Precarious work, insecure workers: Employment relations in transition, American Sociological Review 74, p. 1 - 22.

Karabchuk T. (2012). Temporary employment in Russia: why mostly men? The European Journal of Comparative Economics Vol. 9, n. 2, p. 279-303. 
Karabchuk, T. (2012). Part-time and temporary workers in Russia: winners or losers? In: Journal for Labour Market Research, Vol. 45, No. 1, p. 23-39.

Keller, B. and Seifert, H. (2007). Atypische Beschäftigungsverhältnisse. Flexibilität, soziale Sicherheit und Prekarität, in: Keller, B./Seifert, H. (Hrsg.): Atypische Beschäftigung - Flexibilisierung und soziale Risiken, Berlin, p. 11-26.

Kohaut, S., Lehmer, F., Crimmann, A., Ziegler, K. Ellguth, P., (2009). Forschungsbericht zum Thema „Arbeitnehmerüberlassung“, IAB, Nürnberg.

Kvasnicka, M. (2008). Does Temporary Work Help Provide a Stepping Stone to Regular Employment? NBER Discussion Paper 13843. Cambridge.

Lancker, Wim Van (2012). The European world of temporary employment. In: European Societies, Vol. 14, No. 1, p. 83-111.

Lazear, E. (1990). Job Security Provisions and Unemployment, Quarterly Journal of Economics, 55, pp. 699-726.

Malzeva I.O., Roschin S.Y. (2006). Gender segregation and labor mobility in the Russian labor market. HSE, Moscow.

Milner, J.M. and Pinker, E.J. (2001). Contingent labor Contracting under demand and supply uncertainty. In: Management Science, 47. Jg. H. 8, p 1046-1062.

Mückenberger, U. (1985). Die Krise des Normalarbeitsverhältnisses - hat das Arbeitsrecht noch Zukunft? Zeitschrift für Sozialreform, 31. p. 415-434; p. 457-475.

Mückenberger, U. (2007). Folgerungen aus der Krise des Normalarbeitsverhältnisses, in: Lorenz, Frank; Schneider, Günter (Hg.): Ende der Normalarbeit? Mehr Solidarität statt weniger Sicherheit - Zukunft betrieblicher Interessenvertretung, Hamburg, p. 80 - 109.

Mückenberger, U. (2010). Krise des Normalarbeitsverhältnisses - ein Umbauprogramm, Zeitschrift für Sozialreform 56, p. 403 - 420.

Neubäumer, R. and Tretter, D. (2008). Mehr atypische Beschäftigung aus theoretischer Sicht, Industrielle Beziehungen, 15, S. 256-278.

Nielen, S. and Schiersch, A. (2012). Productivity in German manufacturing firms: Does fixedterm employment matter?," Schumpeter Discussion Papers sdp12004, Universitätsbibliothek Wuppertal, University Library.

OECD (2004), OECD Employment Outlook, OECD Publishing.

OECD (2009), OECD Economic Surveys. Russian Federation, OECD Publishing.

OECD (2011), OECD Reviews of Labour Market and Social Policies: Russian Federation 2011, OECD Publishing.

Pfarr, H. et. al. (2004). REGAM-Studie: Atypische Beschäftigung den Betrieben - eingesetzt zur Umgehung des Kündigungsschutzes? Betriebs-Berater, 59. Jg. H. 11, s. 602-608. 
Pfeifer, C. (2005). Flexibility, Dual Labour Markets, and Temporary Employment - Empirical Evidence from German Establishment Data, Management Revue, 16, p. 404-22.

Portugal, P. and Varejão, J. (2009). Why Do Firms Use Fixed-Term Contracts? IZA DP No. 4380 .

Riphahn R. and A. Engellandt, (2005). Temporary Contracts and Employee Effort, Labour Economics, 12(3), p. 281-299.

Rosstat of RF (2011). Rating of economic activities on an average monthly gross wages without payment of a social nature, Rosstat, July.

Saint-Paul, G. (1991). Dynamic labor demand with dual labor markets. Economics Letters, 36 Jg., pp. 219-222.

Saint-Paul, G. (1996). Dual Labor markets: a macroeconomic perspective. London.

Smirnych, L.I. and Wörgötter, A. (2000), Einkommen, Geschlecht und Arbeitsplatzwechsel in Russland 1998. Earnings, Gender, and Mobility in the RF 1995-1998, Transition Economics Series 15, Institute for Advanced Studies.

Smirnykh, L.I. (2010). Non-standard employment contracts: the experience of enterprises, Paper HSE WP15/2010/3, NRU HSE, Moscow.

Stephan, G. (1991). Fehlzeiten: Eine theoretische und empirische Untersuchung mit Individualdaten. Mitteilungen der Arbeitsmarkt- und Berufsforschung, 24 Jg., H. 3, s. 583-594.

Stephan, G. (1994). Fehlzeiten im Unternehmensvergleich: Wirkt sich die Entlohnung aus? IfoStudien, 40. Jg., s. 43-61. 


\section{WORKING PAPERS}

The full series of Economics Department Working Papers can be consulted at www.oecd.org/eco/workingpapers/

1013. The Equity implications of fiscal consolidation (January 2013) by Lukasz Rawdanowicz, Eckhard Wurzel and Ane Kathrine Christensen

1012. The Dutch labour market: preparing for the future (January 2013) by Mathijs Gerritsen and Jens Høj

1011. Reforming policies for the business sector to harvest the benefits of globalisation in the Netherlands

(January 2013) by Mathijs Gerritsen and Jens Høj

1010. Health care reform and long-term care in the Netherlands (January 2013) by Erik Schut, Stéphane Sorbe and Jens Høj

1009. Enhancing the inclusiveness of the labour market in Belgium (January 2013) by Jens Høj

1008. Reducing poverty in Estonia through activation and better targeting (December 2012) by Sarah Flèche and Artur Radziwill

1007. Matching skills and jobs in Estonia (December 2012) by Lilas Demmou

1006. Debt and macroeconomic stability: An overview of the literature and some empirics (December 2012) by Douglas Sutherland and Peter Hoeller

1005. Debt and macroeconomic stability: Debt and the business cycle (December 2012) by Volker Ziemann

1004. Debt and macroeconomic stability: Case studies (December 2012) by Rossana Merola

1003. Debt and macroeconomic stability (December 2012) by Douglas Sutherland, Peter Hoeller, Rossana Merola and Volker Ziemann

1002. Reducing greenhouse gas emissions in a cost effective way in Switzerland. (December 2012) by Anita Wölfl and Patrizio Sicari

1001. Strengthening innovation in the United States (November 2012) by David Carey, Christopher Hill and Brian Kahin 
1000. Long-term growth scenarios

(forthcoming) by Åsa Johansson, Yvan Guillemette, Fabrice Murtin, David Turner, Giuseppe Nicoletti, Christine de la Maisonneuve, Philip Bagnoli, Guillaume Bousquet and Francesca Spinelli

999. Selected aspects of household savings in Germany - evidence from micro-data (November 2012) by Christina Kolerus, Isabell Koske and Felix Hüfner

998. Improving the tax system in Indonesia

(November 2012) by Jens Arnold

997. Unleashing business innovation in Canada

(November 2012) by Alexandra Bibbee

996. Public policy and resource allocation: evidence from firms in OECD countries (October 2012) by Dan Andrews and Federico Cingano

995. Promoting SME development in Indonesia (October 2012) by Annabelle Mourougane

994. Portugal: Rebalancing the economy and returning to growth through job creation and better capital allocation.

(October 2012) by Álvaro Pina and Ildeberta Abreu

993. Public debt, economic growth and nonlinear effects: Myth or reality?

(October 2012) by Balázs Égert

992. Choosing the pace of fiscal consolidation (September 2012) by Lukasz Rawdanowicz

991. Tertiary education developing skills for innovation and long-term growth in Canada (September 2012) by Calista Cheung, Yvan Guillemette and Shahrzad Mobasher-Fard

990. Trade and product market policies in upstream sectors and productivity in downstream sectors: firm-level evidence from China

(September 2012) by Maria Bas and Orsetta Causa

989. Intangible assets, resource allocation and growth: a framework for analysis (September 2012) by Dan Andrews and Alain de Serres

988. Current account benchmarks for Turkey

(September 2012) by Oliver Röhn

987. Structural reforms to boost Turkey's long-term growth (September 2012) by Rauf Gönenç, Oliver Röhn, Vincent Koen and Şeref Saygili

986. Tackling Turkey's external and domestic macroeconomic imbalances

(September 2012) by Oliver Röhn, Rauf Gönenç, Vincent Koen and Ramazan Karaşahin 